\title{
Green or Greed? \\ An Alternative Look at CEO Compensation and Corporate Environmental Commitment
}

\author{
Claude Francoeur* \\ claude.francoeur@hec.ca
}

Andrea Melis**

melisa@unica.it

Silvia Gaia***

sgaia@essex.ac.uk

Simone Aresu**

simonearesu@unica.it

\footnotetext{
* HEC Montréal

**University of Cagliari

*** University of Essex
} 


\title{
Green or Greed? \\ An Alternative Look at CEO Compensation \\ and Corporate Environmental Commitment
}

\begin{abstract}
This study relies on environmental stewardship, a stakeholder enlarged view of stewardship theory, and institutional theory to analyze the relationship between CEO compensation and firms' environmental commitment in a worldwide sample of 520 large listed firms. Our findings show that environment friendly firms pay their CEOs less total compensation and rely less on incentive-based compensation than environment careless firms. This negative relationship is stronger in institutional contexts where national environmental regulations are weaker. Our findings have important theoretical meaning and practical implications. Results show that CEOs do not necessarily act opportunistically; rather some of them may be willing to act as stewards of the natural environment and accept a lower, less incentive-based, compensation from environment friendly firms. This study also provides evidence of the important influence of the institutional context in setting-up CEO compensation as the relationship is stronger when national environmental regulations are weaker. Our findings question the universal validity of agency theory in explaining CEO compensation. Compensation based on pecuniary incentives might be less indicated to motivate CEOs who feel rewarded by playing a stewardship role for environment friendly firms. When designing compensation for CEOs, compensation committees and external compensation advisors should consider psychological and institutional factors that might affect CEO motivation.
\end{abstract}

Keywords: CEO compensation, corporate social performance, corporate social responsibility, environmental commitment, environmental regulations, stewardship theory. 


\section{Introduction}

Environmental issues represent nowadays a major social concern. Human beings and firms are subject to greater public pressure to reduce their negative environmental impact (Jones, 2014). To react to this external pressure and strengthen relations with stakeholders, firms implement strategies to achieve greater environmental performance (Dowling and Pfeffer, 1975; Berrone and Gomez-Meja, 2009a). There is a growing literature, based on agency theory, which argues that firms that want to reduce their negative environmental impact should include environmental performance as a criterion in setting-up CEO incentive compensation (e.g. Coombs and Gilley, 2005; Berrone and Gomez-Meja, 2009a). According to agency theory, CEO compensation, and in particular its incentive-based component is a primary mechanism to create alignment of interests between rationally bounded principals and opportunistic agents (Jensen and Meckling, 1976).

Following Cuevas-Rodríguez et al. (2012), who called for alternative theoretical perspectives to extend agency theory outside its boundaries, we offer an alternative view by combining stakeholder and stewardship theories to explain the differences in CEO compensation, in terms of magnitude and design, between environment friendly and environment careless firms. In addition, we use the theoretical lenses provided by institutional theory to investigate the moderating role of the institutional context in a worldwide sample of 520 large listed firms.

Agency theory mainly focuses on agency problems in a bilateral relationship, as managers are responsible to satisfy primarily shareholders' interest. Its assumptions have been criticized to be too restrictive. According to several authors (e.g., Tirole, 2002; Cuevas-Rodríguez et al., 2012) other behavioral perspectives may provide more useful insights. For instance, stakeholder theory extends the agency theory view by suggesting that managers should attempt to meet the demands of a wide range of stakeholders including those of the shareholders (e.g. Freeman, 1984; Hill and Jones, 1992; Wood and Jones, 1995). In this view, CEO's decisions and actions should be directed at satisfying all firm's stakeholders (Clarkson, 1995; Wood and Jones, 1995; Jones and Wicks, 1999). Among the stakeholders, the natural environment has a vital role. Human beings and firms have a moral 
responsibility towards the natural environment as their activities impact and are affected by the natural environment (Jones, 2014). By combining agency and stakeholder theories, previous literature suggests that firms wanting to increase their environmental commitment should provide their CEOs explicit incentives to engage in environmental strategies (e.g. Stanwick and Stanwick, 2001, 2003; Cordeiro and Sarkis, 2008; Berrone and Gomez-Meja, 2009a).

In contrast to agency theory, stewardship theory considers managers as non-opportunistic and selfmotivated. Stewardship theory is based on the idea that CEOs are guided by the imperative of doing the right thing even if it does not increase their personal well-being (Davis et al., 1997). By doing so, CEOs have intrinsic benefits not driven by economic values (Berrone and Gomez-Mejia, 2009b). Stewardship theory, in the form of 'environmental stewardship' (Jones, 2014), can explain how some CEOs, and consequently the firm, may be willing to act towards the natural environment. According to Etzioni (1986), the behaviour of these CEOs is driven by a form of moral duty and/or altruism. Such CEOs have an intrinsic motivation to lead the firm to the achievement of non-selfinterested goals. To the extent that these CEOs act as stewards towards the natural environment, they give more importance to moral duties and intrinsic benefits and their interest for financial compensation is relatively weakened. Institutional theory suggests that not only performance outcomes, but also other factors such as social, cultural and political beliefs, industry norms, legislation, and management values influence the design of CEO compensation (Meyer and Rowan, 1977; Eisenhardt, 1988; Wiseman et al., 2012).

This study contributes to the existing literature in several ways. First, it provides new insights on executive compensation research, which is mainly based on agency theory (e.g. Jensen and Murphy, 1990, Tosi and Gomez-Meja, 1994; Berrone and Gomez-Meja, 2009a), by considering the theoretical lenses provided by stewardship, stakeholder and institutional theories. This extended framework provides an alternative perspective to explain CEO compensation's design strategies that are not considered efficient under the restricted agency theory assumptions (e.g. Stanwick and Stanwick, 2001; Coombs and Gilley, 2005). 
Second, by focusing on the firms' commitment to the natural environment, this study answers the call of Johnson and Greening (1999) to investigate specific corporate social responsibility dimensions. We focused on the environment dimension as the natural environment is the primary and primordial 'stakeholder' of the firm (Driscoll and Starik, 2004; Jones, 2014). Several authors (e.g., Stanwick and Stanwick, 2001; Coombs and Gilley, 2005; Cordeiro and Sarkis, 2008, Berrone and Gomez-Meja, 2009a) have called for more investigation in this as it is unclear whether the link between environmental performance and CEO compensation is symbolic, rather than substantial, and positive, rather than negative.

Third, by using a worldwide sample of large listed firms belonging to different institutional settings, this study extends the generalizability of the results compared to studies that adopted a single institutional setting. Several studies had pointed that the institutional context is likely to affect corporate social responsibility (Matten and Moon, 2008; Jackson and Apostolakou, 2010) as well as corporate governance practices (Aguilera and Jackson, 2003) and, in particular, CEO compensation (Filatotchev and Allcock, 2010).

Fourth, we evaluate firms' environmental commitment by using a comprehensive environmental performance measure. Our measure is based on the scores compiled by the Sustainable Investment Research International Company (hereafter SiriPro) - the world's largest company specializing in the analysis of socially responsible performance.

The paper is structured as follows. Section 2 provides the literature review and hypothesis development. Section 3 illustrates the research methodology, followed by the findings in Section 4 . The discussion and conclusions are presented in Sections 5 and 6.

\section{Literature review and hypotheses development}

External pressure regarding environmental issues has resulted in an increasing motivation for individuals and firms to adopt environmental practices (Buysse and Verbeke, 2003; Eesley and Lenox, 2006; Sarkis et al., 2010; Endrikat, et al. 2014; Jones, 2014). 
To respond to these pressures, according to a combined view of agency and stakeholder theories, CEOs compensation should be explicitly linked to environmental performance so that it provides CEOs the incentive to pursue environmental goals (Berrone and Gomez-Meja, 2009a).

Present research on the relationship between CEO compensation and environmental performance is scarce. Most studies have focused on the US institutional context and found mixed evidence. On the one hand, Cordeiro and Sarkis (2008) found that environmental performance influences CEO compensation levels only in firms where there is an explicit linkage between environmental performance and CEO compensation. Berrone and Gomez-Meja (2009a) focused on firms operating in environmentally sensitive sectors. They found that firms enjoying good environmental performance reward their CEOs accordingly. On the other hand, Stanwick and Stanwick (2001) and Coombs and Gilley (2005) found an inverse relationship between CEO compensation and environmental reputation/performance. By adopting a stakeholder enlarged view of agency theory, they interpreted their findings by arguing that firms with higher environmental performance gave CEOs incentives to decrease their focus on environmental strategies. However, other theories may provide alternative explanations for this evidence.

\subsection{Theoretical framework}

The adoption of contractual mechanisms to provide CEO incentives to pursue stakeholders' interests is based on the assumptions that CEOs act in a self-interest, opportunistic, rational way. These assumptions rule out the possibility that CEOs, as any individual, may in fact obtain emotional or social benefit in fulfilling stakeholders' expectations. However, individuals including CEOs - may have reasons for pursuing goals other than their own self-interest. As Sen (1987: 85) argues, 'behavior is ultimately a social matter'... 'thinking in terms of what 'we' should do, or what should be 'our' strategy, may reflect a sense of identity involving recognition of other people's goals and the mutual interdependencies involved'. It can be part of rationality that an individual could try to do his/her best to achieve what s/he would like to achieve, and this can also 
include the promotion of non-self-interested goals which s/he may value and wish to aim at (Sen, 1987). This notion of rationality is in line with the assumptions of stewardship theory, which predicts that individuals, including CEOs, essentially want to do 'the right thing', as they are far from being opportunistic (e.g. Donaldson and Davis, 1989; Davis et al., 1997). CEOs may act as stewards who perceive greater utility in adopting pro-organizational and collectivistic, rather than individualistic and merely self-serving behaviors (Davis et al., 1997). Stewardship theory assumes that individuals identify themselves with the mission of the organization and/or are intrinsically motivated to pursue organizational goals. Individuals who are intrinsically motivated may perform an activity without 'apparent rewards except the activity itself' (Deci, 1971: 105). By pursuing organizational goals and attributing the organizational successes to themselves, CEOs increase their 'self-image and self-concept' (Davis et al., 1997). Stewardship theory can explain not only the commitment of CEOs towards the shareholders, but also their commitment towards other stakeholders (Godos-Díez et al., 2011), such as the natural environment, which is the primary and primordial stakeholder (Driscoll and Stark, 2004, Jones, 2014). According to Jones, (2014: p. 23), human beings are stewards of the natural environment. They, as the dominant species on the planet, have the moral duty to protect, enhance if possible, but certainly not deplete the world's natural resources (Jones, 2014). This behaviour is in line with the concept of environmental stewardship as an ethical duty. Human beings shall take care of the natural environment because, according to their set of moral values, this is the right thing to do (Etzioni, 1986). Human beings might also undertake environmentally sound actions because they enjoy acting in this way, as they receive an intrinsic (i.e. non-pecuniary) reward in acting in this manner, such as a moral satisfaction or a social approval (Andreoni, 1989; Holländer, 1990).

Stewardship theory can incorporate an institutional perspective, thereby giving explicit recognition to the social contexts surrounding corporate social responsibility (Aguilera et al., 2007). The institutional context may influence the development and the diffusion of corporate social responsible practices (e.g, Jones, 1999; Matten and Moon, 2008; Jackson and Apostolakou, 2010). 
Institutional theory addresses the embeddedness of firms in a nexus of formal and informal rules (DiMaggio and Powell, 1983). These rules range from strict regulations to less formal constraints. The institutional perspective on corporate social responsibility suggests that firms' social and environmental strategies are influenced by the diversity of institutional settings and social and environmental regulations (Jones, 1999; Aguilera and Jackson, 2003; Matten and Moon, 2008; Jackson and Apostolakou, 2010). Thus, CEOs' environmental stewardship can be affected by the institutional context surrounding the firm.

Therefore, we derive our hypotheses from stewardship theory. We also investigate the role of national environmental regulations as institutional moderator of the relationship between firm's environmental commitment/performance and CEO compensation.

\subsection{Hypotheses' development}

Relying on stewardship theory, we predict that CEOs who see themselves as stewards of the natural environment do not act in a merely self-interested way; rather they pursue non-self-interested goals. These CEOs may act in such a way because they are intrinsically motivated, either by an ethical duty or an altruistic attitude. Previous studies argued that people working in non-profit organizations are intrinsically motivated by the desire to perform the organizational tasks and pecuniary incentives play a less important role (e.g. Frank, 2003; Benz, 2005; Jobome, 2006; BenNer et al., 2010). Similarly, firms that aim at social and environmental goals are likely to select those CEOs who are self-motivated and whose interests are naturally aligned with those of the firm (e.g. Frank, 2003; McGuire et al., 2003; Brekke and Nyborg, 2008; Berrone and Gomez Meja, 2009b; Cai et al. 2011; Grolleau et al. 2012). These CEOs will avoid firms that strictly adopt a single "bottom-line"1 approach (McGuire et al., 2003). As CEOs are recognized organizational leaders, their environmental commitment will lead other directors and employees to act in the same way towards the natural environment (e.g., Hernandez, 2008). This will in turn influence the ethical climate within the firm (e.g., Berrone and Gomez-Mejia, 2009a, Blome and Paulraj, 2013). Indeed, 
social performance has been found to be primarily due to managerial beliefs of corporate culture (McGuire et al, 2003). Therefore, the CEO and the whole firm will try to serve as stewards of the natural environment (Jones, 2014).

From this perspective, the adoption of incentive-based compensation to managers may be ineffective and, even worst, might crowd out intrinsic incentives and/or pro-social behaviors (e.g. Frey and Jegen, 2001; Fehr and Falk, 2002; Bénabou and Tirole 2003; Cuevas-Rodríguez et al., 2012; Ims et al., 2014). If CEOs serve as stewards, there is less of a need to use explicit incentives to align their interest with those of the stakeholders, as their interests are already focused on organizational, rather than personal aims. Moreover, explicit incentives, such as financial rewards, aim at directing managers' attention towards shareholders and can detract them from serving the interests of other 'principals', like the natural environment (Deutsch and Valente, 2013). Explicit incentives may also decrease the individual's willingness to allocate time and efforts towards social activities, as they reduce the sense of control s/he has over his (her) actions (Berrone and Gomez Meja, 2009b). Thus, incentive-based compensation can weaken individual's intrinsic incentives and produce unintended negative consequences (Ims et al., 2014). According to this perspective, socially concerned firms have been found to rely more on lower-powered incentive contracts, such as salaries, than non-socially concerned firms (e.g. Frye et al., 2006; Kopel and Brand, 2013). Therefore, we expect that:

H1. Environment friendly firms are less likely to pay their CEO with incentive-based compensation.

Environment friendly firms might rely less on compensation to reward their CEO, as CEOs might be already intrinsically rewarded by the contribution they give to safeguard the natural environment. This is coherent with the concept of 'impure' altruism: people increase their utility from the act of giving (Andreoni, 1989). CEOs who have internalized non-monetary values into their preferences might, thus, prefer working for firms regarded as responsible towards the natural environment as 
they get an intrinsic reward by working for them (Brekke and Nyborg, 2008). Assuming that individuals' utility increases with their altruistic behavior, firms regarded as responsible towards the natural environment are more likely to pay their CEO less and these CEOs accept such lower compensation as they are likely to gain an intrinsic benefits from their job, when compared with CEOs of environmental careless firms.

CEOs that act as stewards are likely to be willing to accept a relatively lower compensation than CEOs that are motivated only by self-interested considerations, as the former gain more intrinsic benefits from their job (Benz, 2005; Wasserman, 2006; Moriarty, 2009). These CEOs are hence more willing to accept lower pecuniary compensation in socially concerned firms, such as firms committed to environmental sustainability, as they strive to get a moral satisfaction, that they would not obtain in non-socially concerned firms (e.g. Brekke and Nyborg, 2008; Nyborg and Zhang, 2013). For instance, people who work in non-profit organizations have been found to receive lower compensation in comparison with those working in for-profit firms (e.g. Frank, 2003; Benz, 2005). This supports the assumption that people working in socially concerned firms seem to be motivated by reasons other than pecuniary (Benz, 2005). Therefore, in setting CEO compensation, board of directors of these firms should pay more attention to psychological factors that underlie CEOs' motivation to pursue the goals of the firm (Jobome, 2006). By contrast, the board of directors of firms that are less socially-concerned might need to offer a compensating wage premium to motivate their CEOs as they do not to get any additional intrinsic benefit from their work (Frank, 2003). CEO compensation is at best the result from an arm's length negotiation between the board of directors and the $\mathrm{CEO}^{2}$. In this negotiation both the board of directors and the CEO should act as fiduciary for stakeholders and place the firms' interests ahead of their own interests (Moriarty, 2009). On one hand, the board of directors has the fiduciary duty to attempt to design the most costefficient compensation packages in order to attract, retain, and motivate CEOs to maximize firm value (Jensen et al. 2004). On the other hand, the CEO has the fiduciary duty not to seek and accept a compensation that is higher than the amount necessary to be attracted, retained and motivated to 
maximize firm value (Moriarty, 2009). This fiduciary duty explains why in environment friendly firms CEOs, who are intrinsically rewarded by working for these firms, may be more willing to accept a lower compensation than CEOs in less environment friendly firms. Therefore, we expect that:

H2. Environment friendly firms are more likely to pay their CEO less.

The institutional context may influence corporate social responsible practices (Jones, 1999; Matten and Moon, 2008; Jackson and Apostolakou, 2010). According to institutional theory firms are embedded in a nexus of formal and informal rules (DiMaggio and Powell, 1983). These rules range from strict political regulations to less formal constraints. Firms' environmental strategies are influenced by the diversity of institutional settings and environmental regulations (Fiorino, 2006; Jackson and Apostolakou, 2010). Strong mandatory environmental regulations are created to exercise pressure on firms' environmental commitment. Thus, in these institutional settings, even self-interested CEOs might pursue environmental corporate strategies to comply with the regulation and avoid fines, liabilities and litigation costs (Kock et al. 2012). By contrast, in countries where firms' environmental commitment is not strongly regulated, more room exists for firms to develop environmentally sound strategies on a voluntary basis. The potential motivations behind the voluntary adoption of corporate environment friendly initiatives are manifold. Environmentally sound initiatives may help firms improving their efficiency in the manufacturing processes and/or attract more profitable consumers, such as environment-concerned consumers. They may also contribute to respond to stakeholders' pressures or to pursue ethical and social values (Lyon and Maxwell, 1999; Bansal and Roth, 2000; Endrikat et al. 2014). Environment friendly firms operating in countries with a weak environmental protection need to be managed by CEOs with an environmental vision. These CEOs will be self-motivated in developing environment-oriented strategies as they are willing to act as stewards of the natural environment, despite the lack of strict 
environmental regulations. CEOs who act as stewards of the natural environment get intrinsic benefits in pursuing corporate environmental sustainability and are willing to accept a lower compensation. There is also less of need to use incentive-based compensation than when CEOs pursue environmental strategies mainly to comply with regulations. As the need to have CEOs with an environmental vision is greater in an institutional context where firms' environmental commitment is not strictly regulated, it is likely that environment friendly firms rely less on incentive-based compensation (and more on fixed salaries) and pay their CEOs less than environment friendly firms whose environmental commitment is mandated by national environmental regulations. Therefore, we expect that:

H3a. The negative relation between environment friendly firms and the use of incentive-based compensation to pay CEOs is stronger in firms that are headquartered in countries with weaker environmental regulations.

$H 3 b$. The negative relation between environment friendly firms and CEO compensation is stronger in firms that are headquartered in countries with weaker environmental regulations.

\section{Methodology}

\subsection{Sample and data gathering}

Our sample is drawn from several databases. The SiriPro database is assembled by Sustainable Investment Research International (SIRI), the world's largest firm specializing in socially responsible investment analysis. SIRI corporate social performance (CSP) evaluation is not provided upon firm request, therefore avoiding self-selection bias (Cheng and Courtenay, 2006).

Firms included in the SiriPro database are then matched with those whose CEO compensation is available in the BoardEx database. We drop both the firms for which a CEO could not be identified and the firms with a CEO who left during the financial year. This lead to a sample of 601 non- 
financial listed firms. Firms' financial performance data (ROA and stock return), risk, size, leverage and industry classification were collected using Osiris database. Because of missing and extreme values $^{3}$ in those variables we lost 81 observations. Our final sample is composed of 520 nonfinancial listed firms headquartered in 17 countries.

\subsection{Model}

To test our hypotheses we used OLS regression models with industry-fixed effects $\left(\mu_{\mathrm{i}}\right)$. In particular, the following two models were adopted to test, respectively, hypothesis 1 and hypothesis 2:

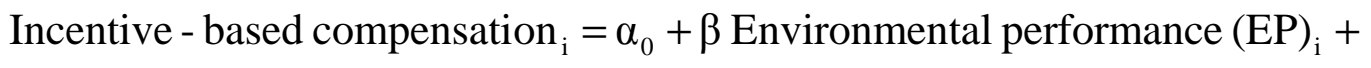

$$
+\delta \text { control variables }{ }_{\mathrm{i}}+\mu_{\mathrm{i}}+\varepsilon_{\mathrm{i}}
$$

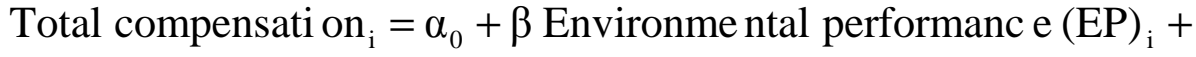

$$
\begin{aligned}
& +\delta \text { control variables }{ }_{i}+\mu_{i}+\varepsilon_{i}
\end{aligned}
$$

To test hypotheses $3 \mathrm{a}$ and $3 \mathrm{~b}$ we add the interaction term Environmental Performance (EP) $\times$ Environmental Regulatory Regime Index (ERRI). This allows to analyse the moderating role played by the institutional setting on the relationship between firms' environmental performance and CEO compensation.

$$
\begin{aligned}
\text { Incentive- based compensation }_{\mathrm{i}}= & \alpha_{0}+\beta_{1} \mathrm{EP}_{\mathrm{i}}+\beta_{2} \mathrm{ERRI}_{\mathrm{i}}+\beta_{3} \mathrm{EP}_{\mathrm{i}} \times \mathrm{ERRI}_{\mathrm{i}} \\
& +\delta \text { control variables } \\
\mathrm{i} & +\mu_{\mathrm{i}}+\varepsilon_{\mathrm{i}}
\end{aligned}
$$

$$
\begin{aligned}
\text { Total compensation }_{\mathrm{i}}= & \alpha_{0}+\beta_{1} \mathrm{EP}_{\mathrm{i}}+\beta_{2} \text { ERRI }_{\mathrm{i}}+\beta_{3} \mathrm{EP}_{\mathrm{i}} \times \mathrm{ERRI}_{\mathrm{i}}+ \\
& +\delta \text { control variables }_{\mathrm{i}}+\mu_{\mathrm{i}}+\varepsilon_{\mathrm{i}}
\end{aligned}
$$

\subsubsection{Dependent variables}

The dependent variables in our regression models are based on the 2009 CEO compensation. To test our hypotheses, we consider two CEO compensation measures: the proportion of incentivebased compensation and total compensation. Consistent with previous studies (e.g. Jensen and Murphy, 1990), total CEO compensation was measured as the sum of CEO salary, bonus, the value 
of equity based compensation (valued at the year-end closing stock price) and other compensation, as reported in the BoardEx database. The natural logarithm of this variable was used to offset skewness in the distribution. The proportion of incentive-based compensation was measured as the ratio between equity-based compensation and CEO total compensation.

\subsubsection{Independent variables}

Environmental performance (EP). To estimate the degree of firms' commitment to environmental sustainability we used the SiriPro "environmental performance" (EP) ratings. SiriPro performs this analysis based on actual performance, reporting procedures, policies and guidelines, management systems and other key data. The necessary information is extracted from financial accounts, corporate documentation, international databases, media reports, interviews with key stakeholders and ongoing contact with management. The information extracted from each firm is condensed into 62 information items on the environmental impact. SiriPro evaluates the environmental impact in four areas: levels of transparency in public reports and communications (2); the existence of corporate policies and principles (5); the importance of management systems (27) and the level of the firm's environmental performance (28). Therefore, the SiriPro "environmental performance" index, comprises both measures of commitment (e.g., the existence of corporate policies and principles, an environmental management system, etc.), and performance (e.g., CO2eq emissions, renewable energy consumption, air emissions, and so on). Each issue is given a score ranging from 0 (worst) to 100 (best). Importantly, each information item is weighted according to a methodology developed by SiriPro. Environmental performance (EP) is measured at the end of the previous financial year. The list of the 62 items is reported in the appendix.

Environmental Regulatory Regime Index (ERRI). We test the moderating influence of the institutional setting on the relationship between firms' environmental commitment/performance and CEO compensation by measuring the level of each country's set of environmental regulations with 
the Environmental Regulatory Regime Index (ERRI) as in Esty and Porter (2005). This index measures the level of country environmental regulations quality considering the following elements: a) stringency of standards; b) sophistication of the regulatory structure; c) subsidization of natural resources and d) strictness of regulatory enforcement. The 'stringency of standards' measures the perceived rigor of countries' regulations on air pollution, water pollution, toxic waste, and chemicals. The 'sophistication of the regulatory structure' measures the degree to which countries' environmental regulations are flexible, clear, consistent and structured to encourage competitiveness, and designed to promote cooperative, rather than adversarial, business-government relations. The 'subsidization of natural resources' measures the extent to which a country subsidizes energy and other materials. The 'strictness of regulatory enforcement' measures how aggressively a country's environmental regulations are enforced.

Table 1 lists the 17 countries included in our sample according to their ERRI scores. Finland. Sweden, Singapore, Netherland and Austria are among the most regulated countries towards the environment. By contrast, Portugal, Spain, Italy, Ireland and Norway are the least regulated. We coded each firm in the sample according to the ERRI score of the country in which the firm is headquartered.

\section{INSERT TABLE 1}

\subsubsection{Control variables}

We also control for the following variables:

- Firm size: Previous studies show that larger firms are able to pay more attention to their stakeholders (Waddock and Graves, 1999; Mc Williams and Siegel, 2001; Cai et al., 2011). Firm size is also an important determinant of CEO compensation because larger firms hire CEOs with superior skills (Rosen, 1982) and CEOs who are risk averse, prefer linking their pay to a stable factor such as firm's size, rather than performance (Tosi et al., 2000). Firm size is measured as the natural logarithm of total assets at the end of the previous financial year. 
- Financial performance is known to be an important driver of CEO compensation (Hall and Liebman, 1988). Several studies support the existence of a positive relationship between financial performance and corporate social performance (Callan and Thomas, 2011). Financial performance is measured by the accounting and market performance (ROA and stock return, in percentages) during the previous financial year.

- Financial leverage: The level of debt may influence firms' likelihood to use CEO compensation as a tool for solving the agency problem (Shleifer and Vishny, 1997). It is measured as the ratio of total debt on total assets at the end of the previous financial year.

- Firm risk: Previous research shows the existence of a complex and non-linear relationship between firm risk and both total compensation and the use of performance-contingent compensation for CEOs (Miller et al., 2002). Risk is measured by using the firm's market beta at the end of the previous financial year.

- Industry: Risks and opportunities for improving environmental performance vary across industries (Russo and Fouts, 1997; McGuire et al., 2003; Berrone and Gomez-Mejia, 2009a). Moreover, industry mean compensation is used as a benchmark by which investigating whether a CEO's compensation is in line with that of peers (Jensen and Murphy, 1990; Aggarwal and Rajesh, 1999). We group firms following the one-digit Standard Industry Classification (SIC) codes. Thus, Industry is a set of dichotomous variables that are equal to 1 if the firm belongs to a given $i$ industry and 0 otherwise.

\section{Results}

\subsection{Sample descriptive statistics and univariate analysis}

Table 2 reports descriptive statistics on the level of CEO compensation in the whole sample and in the 17 countries analyzed. On average, CEOs receive a total compensation of $\$ 10$ million dollars (median value around \$7 million), with incentive-based compensation accounting for more than $27 \%$ of total compensation. Consistently with previous studies (e.g. Fernandes et al., 2013) 
firms headquartered in the US, followed by UK firms, are those with the highest paid CEOs and that use incentive-based compensation the most. By contrast, CEOs are paid the least in Spanish and Portuguese firms. Incentive-based compensation was never adopted by Austrian, Italian and Spanish firms.

\section{INSERT TABLE 2}

Table 3 reports descriptive statistics on the level of firm's environmental performance and the other variables considered in the study. Firm' environmental performance has mean and median values around the middle of its range of definition (45.0 and 44.3, respectively). With respect to financial performance, ROA mean and median values are above 5\%, while stock return mean and median values are below $-37 \%$, due to the share price drop in 2008 . Firm size ranges from $\$ 142$ million to $\$ 372$ billion in total assets, with mean and median values of $\$ 21$ and $\$ 7.7$ billion, respectively. Firm leverage is, on average, higher than $60 \%$ and Beta risk is, on average, close to 1 . Half of the firms in the sample operate in the light and heavy manufacturing industries.

\section{INSERT TABLE 3}

Multicollinearity diagnostics, using VIFs (maximum VIF value 2.97, average VIF value 1.76) and the correlation between the independent variables (see table 4), indicate that multicollinearity is unlikely to be a concern.

\section{INSERT TABLE 4}

The correlation matrix shows that firms that exhibit a higher environmental performance/commitment and firms headquartered in countries with a stronger environmental regulation use less incentive-based compensation and pay their CEOs the least. Conversely, larger firms and those with higher stock returns pay their CEOs the most. The use of incentive-based compensation is positively associated with stock market returns. Firms operating in the agriculture, mining and construction industry exhibit a lower environmental performance/commitment. On the other hand, firms in the transportation, communication and utilities industry show a higher score of 
environmental performance. Environmental performance is not significantly correlated with accounting or market performance.

\subsection{Multivariate analysis}

Table 5 reports the results of the regression analyses. In Models 1 and 3 the dependent variable is the CEO incentive-based compensation ratio, while in Models 2 and 4 the dependent variable is the CEO total compensation.

\section{INSERT TABLE 5}

We find that firms with a higher environmental commitment used significantly less incentive-based compensation and paid their CEO significantly less than firms with a lower environmental commitment. Indeed, as shown in Table 5, firms' environmental performance (EP) is negatively and significantly associated with both the incentive-based compensation ratio $(\mathrm{p}<0.01)$ and the total level of CEO compensation ( $\mathrm{p}<0.01)$. Thus both hypotheses 1 and 2 are supported.

We also find that the relationship between environmental performance (EP) and the incentive-based compensation ratio and the total level of CEO compensation is moderated by country's environmental regulations. More specifically, the negative relationship is significantly stronger in institutional contexts where national environmental regulations are weaker. As reported in Table 5, the coefficients for the interaction term between firms' environmental performance (EP) and the Environmental Regulatory Regime Index (ERRI) are positive and significant both in model 3, where the dependent variable is the incentive-based compensation ratio $(\mathrm{p}<0.05)$, and model 4 , where the dependent variable is the total CEO compensation $(\mathrm{p}<0.01)$. Thus, support is provided for hypotheses $3 \mathrm{a}$ and $3 \mathrm{~b}$. Firms committed to the environment use incentive-based compensation and pay their CEO the least in institutional contexts where weaker national environmental regulations are in place. 
We also find that larger and riskier firms, firms with higher stock market performance, firms headquartered in countries with weaker environmental regulations pay their CEOs significantly more and used significantly more incentive-based compensation.

\section{Discussion}

This paper contributes to the academic literature on CEO compensation in sociallyconcerned firms (e.g., Riahi-Belkaoui, 1992; Stanwick and Stanwick, 2001; McGuire et al., 2003; Coombs and Gilley, 2005; Cordeiro and Sarkis, 2008; Cai et al., 2011; Miles and Miles, 2013) by investigating the relationship between firms' environmental commitment and CEO compensation in a worldwide sample of 520 large listed firms. Based on a stakeholder-enlarged view of stewardship theory, this study provides empirical evidence that environment friendly firms use lower levels of total compensation and financial incentives to pay their CEOs.

This study extends the literature in three ways. First, it provides empirical evidence from a worldwide sample of non-financial listed firms, while previous studies focused exclusively on US firms (Stanwick and Stanwick, 2001; Coombs and Gilley, 2005; Cordeiro and Sarkis, 2008; Berrone and Gomez-Meja, 2009a).

Second, we answer the call of previous studies to widen and complement agency theory with other theoretical frameworks (e.g. Tirole, 2002; Cuevas Rodriguez et al., 2012). Previous studies on CEO compensation and environmental strategies (Stanwick and Stanwick, 2001; Coombs and Gilley, 2005; Cordeiro and Sarkis, 2008, Berrone and Gomez-Meja, 2009a) adopted a stakeholderagency theoretical framework and interpreted the results accordingly. These studies explained the negative relationship between CEO compensation and firms' environmental performance as a signal that firm's remuneration policies do not encourage CEOs to be environment friendly (Stanwick and Stanwick, 2001). By contrast, our study provides an alternative explanation by relying on a stakeholder-enlarged view of stewardship theory. Stewardship theory assumes that individuals, including CEOs, place higher values on pro-organisational and collectivistic behaviours than on 
individualistic and self-serving goals (e.g., Donaldson and Davis, 1989; Davis et al., 1997; Sundaramurthy and Lewis, 2003; Hernandez, 2008; Godos-Díez et al., 2011). Stewardship theory can explain the commitment of CEOs towards shareholders and other stakeholders (Godos-Díez et al., 2011), such as the natural environment. When applied to the natural environment, stewardship theory assumes that individuals have a moral responsibility to provide a service towards it (Jones, 2014). This study provides new insights that explain a negative relationship between the use of incentive-based compensation and environmental performance. By taking an environmental stewardship perspective, this study points out that environment friendly firms are likely to rely less on incentive-based plans to pay their CEO as these executives are likely to have their interests already aligned with the environmental goals because they have a moral duty to safeguard the natural environment and receive intrinsic rewards from doing this. In such a context, financial rewards might not only be ineffective (Jobome, 2006), but also have an adverse effect on CEOs intrinsic commitment (Frey and Jegen, 2001; Ben-Ner et al., 2010; Ims et al., 2014).

Environmental stewardship also provides an explanation of why CEOs of environmentfriendly firms freely accept lower financial compensation compared to CEOs of environmentcareless firms. If some CEOs act as stewards towards the natural environment, then it can be argued that these CEOs obtain private enjoyment and utility from this commitment. They are hence willing to trade-off financial compensation for such intrinsic rewards, a privilege that they would not obtain in non-socially concerned firms (e.g. Frank, 2003; Benz, 2005; Brekke and Nyborg, 2008; Nyborg and Zhang, 2013). It could be argued that the board of directors could take advantages of these CEOs who have an ethical character by paying them less. However, we argue that it is unlikely for the board of directors to financially exploit the CEO, as CEO compensation is the result of a negotiation which is much more likely to be dominated by the CEO's rather than by the board (Bebchuk and Fried, 2003).

We also argue that these CEOs see the ethical value in trading less compensation for a better environment. They feel they have the moral duty to place the firms' and society's interests ahead of 
their own interests (Moriarty, 2009). The board of directors has the fiduciary duty to optimize CEO compensation. Consequently, it should pay less compensation to those CEOs who receive intrinsic rewards (Wasserman, 2006). At the same time, the CEO has the fiduciary duty to not accept a compensation that is higher than the amount necessary to be attracted, retained and motivated to maximize firm value (Moriarty, 2009).

Finally, in line with institutional theory, this study contributes to the literature on the relationship between environmental commitment and institutional context (e.g., Bansal and Clelland, 2004; Berrone and Gomez-Meja, 2009a) and supports the view that organizational practices, such as CEO compensation, are influenced by the level of regulations in which a firm is institutionally embedded (e.g., Berrone and Gomez-Mejia, 2009a; Cuevas-Rodríguez et al., 2012). We find that the relationship between firms' environmental commitment and CEO compensation is significantly influenced by the level of national environmental regulations in which a firm is institutionally embedded. More specifically, institutional contexts characterized by weaker environmental regulations and more room for firm's voluntary initiatives drive firms to hire environment friendly CEOs that rely less on financial compensation and more on intrinsic rewards. In these institutional contexts, CEOs will have more opportunities to undertake environmentally sound actions and fulfil their desire to act as true stewards of the natural environment.

\section{Practical implications}

Our findings provide important practical implications. Compensation committees and compensation consultants should take into account the CEO's moral duties and intrinsic benefits in pursuing organizational goals, when designing CEO compensation. In particular, this study suggests that incentive-based compensation is less important in environment friendly firms as their CEOs, being stewards of the environment, are likely to be intrinsically motivated in pursuing environmental goals. This is particularly important for firms in institutional contexts with weak environment 
regulations where the adoption of environmental strategies is due to voluntary initiatives rather than to a mere compliance with environmental regulation.

\section{Limitations}

Our study faces the following limitations and sets opportunities for future research. First, as in previous studies (e.g., Deckop et al., 2006; Cordeiro and Sarkis, 2008; Miles and Miles, 2013), the present research considers a short time horizon. The influence of firms' environmental commitment on CEO compensation could be better explained in a broader longitudinal analysis. Second, we focused our analysis on CEOs of large international listed firms. Our findings may not be generalizable to smaller firms. Third we focused on one dimension of corporate social responsibility: environmental commitment and performance. Results might be different when other specific corporate social responsibility dimensions, such as corporate business ethics, are analyzed. In addition, the environmental index adopted combines firm's environmental commitment and performance in a single measure, so we were unable to provide a deeper analysis. Fourth, given the lack of available data on the location of the firms' facilities, we considered the national environmental regulation of the country where the firm's head offices are located. However, we acknowledge that firms' environmental commitment and performance might also be affected by the national environmental laws of the country that hosts the production facilities. Future research could address these issues.

\section{Conclusion}

Results show a negative relationship between firms' environmental commitment and CEO compensation (in terms of total compensation and proportion of incentive-based compensation). This relationship is moderated by national environmental regulations. Environment friendly firms pay their CEOs less and use less incentive-based compensation in institutional contexts where environmental regulations are less strict. 
These findings provide support to environmental stewardship, a stakeholder enlarged view of stewardship theory, as well as to institutional theory. This study contributes to the debate on the use of incentive-based compensation to encourage the achievement of social and environmental goals. It suggests that CEOs opportunism should not always be assumed when setting up their compensation. Environment friendly firms tend to use lower levels of total compensation and financial incentives to pay their CEOs. In this way, they risk restricting the pool of talent they are able to attract but they are also more likely to select those candidates that better fit their environmental vision. The CEOs they recruit might act as stewards of the natural environment and receive intrinsic benefits by managing environment friendly firms. Our findings also suggest that the characteristics of the institutional context in which a firm is embedded should be taken into consideration in designing CEO compensation. 


\section{APPENDIX \\ SiriPro - Environmental commitment/performance index}

Public Reports and Communications

1. Public reporting on environmental issues

2. Public reporting externally verified

Principles and Policies

3. Environmental policy

4. Formal policy statement on green procurement

5. Formal policy statement on use of certified forestry product

6. Public position statement on transport and climate change

7. Public position statement on energy mix

Management Systems

8. Percentage of ISO 14001 certified sites

9. Targets and programs for environmental improvement of suppliers

10. Targets and programs for $\mathrm{CO} 2 \mathrm{eq}$ emission reduction and/or energy consumption

11. Targets and programs to increase the use of renewable energy

12. Targets and programs to reduce air emissions

13. Targets and programs to reduce hazardous waste generation

14. Targets and programs to reduce non-hazardous waste generation

15. Targets and programs to reduce discharge to water

16. Targets and programs to reduce water consumption

17. Targets and programs to reduce material consumption

18. Targets and programs to phase out use of hazardous substances

19. Targets and programs to phase out CFC's /HCFC's in refrigeration equipment 
20. Targets and programs to replace chlorine bleaching

21. Targets and programs to increase percentage of certified pulp/wood operations

22. Targets and programs to increase use of environmentally-friendly paper

23. Targets and programs to improve the environmental performance of fleet and transport

24. Targets and programs to reduce emissions of transport means

25. Targets and programs to reduce the noise characteristics of transport

26. Targets and programs to phase out production of hazardous substances

27. Targets and programs to reduce the energy consumption of products

28. Targets and programs to reduce the impact of product at the end of the production cycle

29. Targets and programs to reduce the environmental toxicity of product

30. Targets and programs to reduce packaging materials

31. Targets and programs to increase the sale of eco-labeled/organic products

32. Targets and programs to reduce $\mathrm{CO} 2 \mathrm{eq}$ emissions of the fleet

33. Programs that offer favorable financial conditions for environmentally friendly projects

34. Programs to take into account environmental impact of products in investment decision

\section{Performance}

35. Percentage of ISO 14001 certified suppliers

36. Data on $\mathrm{CO} 2 \mathrm{eq}$ emissions

37. Data on renewable energy consumption

38. Data on air emissions

39. Data on hazardous waste generation

40. Data on non-hazardous waste

41. Data on discharge to water

42. Data on oil spills

43. Data on water consumption 
44. Data on material consumption

45. Data on percentage of certified pulp or wood of total consumption/production

46. Data on percentage of recycled fiber as raw material

47. Percentage of FSC paper

48. Percentage of recycled paper used

49. Percentage of renewable energy sold

50. Data on assets managed according to SRI criteria

51. Data on total amount of environmental fines and penalties

52. Total land disturbed and not yet rehabilitated

53. Percentage of sales from eco-labeled/organic products

54. Environmentally friendly construction materials

55. Environmentally friendly building products

56. Products beneficial to the environment

57. Percentage of loans with detailed environmental examination

58. Percentage of environmentally oriented loans

59. Percentage of transactions with detailed environmental examination

60. Percentage of transactions with high environmental benefits

61. Percentage of investments in non-listed pioneer companies with high environmental benefits

62. Percentage of premium volumes or number of policies with environmental incentives

\footnotetext{
${ }^{1}$ As opposed to 'triple bottom line'.

2 At worst, as pointed out by Bebchuk and Fried (2003), the compensation process is dominated by the CEO's interests. Boards do not engage in arms' length negotiations with the CEO over compensation, because they lack the independence, adequate time and easy access to accurate and unbiased information. Moreover, also board members who sit in the compensation committee have economic and social incentives to favor CEOs (e.g., Murphy, 1999).

${ }^{3}$ We used the interquartile range rule to identify outliers.
} 


\section{$\underline{\text { References }}$}

Aggarwal, R. K., and Samwick, A. A. (1999). Executive compensation, strategic competition, and relative performance evaluation: Theory and evidence. The Journal of Finance, 54(6), 1999-2042.

Aguilera, R. V., Jackson, G. (2003). The cross-national diversity of corporate governance: Dimensions and determinants, Academy of Management Review, 28(3): 447-465.

Aguilera, R. V., Rupp, D. E., Williams, C. A., and Ganapathi, J. (2007). Putting the S back in corporate social responsibility: A multilevel theory of social change in organizations. Academy of management review, 32(3), 836-863.

Andreoni, J. (1989). Giving with Impure Altruism: Applications to Charity and Ricardian Equivalence. Journal of Political Economy, 97(6), 1447-1458.

Bansal, P., and Clelland, I. (2004). Talking trash: Legitimacy, impression management, and unsystematic risk in the context of the natural environment. Academy of Management Journal, 47(1), 93-103.

Bansal, P. and Roth, K. (2000). Why companies go green: a model of ecological responsiveness. Academy of Management Journal, 43(4), 717-736.

Bebchuk, L. A., and Fried, J. M. (2003). Executive compensation as an agency problem. Journal of Economic Perspectives, 17, 71-92.

Bénabou, R. and Tirole, J. (2003) Intrinsic and Extrinsic Motivation. Review of Economic Studies 70(3), 489-520.

Ben-Ner, A., Ren, T., \& Paulson, D. F. (2010). A sectoral comparison of wage levels and wage inequality in human services industries. Nonprofit and Voluntary Sector Quarterly, 20(10), 1-26.

Benz, M. (2005). Not for the Profit, but for the Satisfaction? - Evidence on Worker Well-Being in Non-Profit Firms. Kyklos, 58(2), 155-176. 
Berrone, P. and Gomez-Mejia, L.R. (2009a). Environmental performance and executive Compensation: an integrated Agency-institutional perspective. Academy of Management Journal, 52(1), 103-126.

Berrone, P. and Gomez-Mejia, L.R. (2009b). The pros and cons of rewarding social responsibility at the top. Human Resource Management, 48(6), 959-971.

Blome, C., and Paulraj, A. (2013). Ethical Climate and Purchasing Social Responsibility: A Benevolence Focus. Journal of business ethics, 116(3), 567-585.

Brekke, K.A. and Nyborg, K. (2008). Attracting responsible employees: green production as labor market screening. Resource and Energy Economics, 30(4), 509-526.

Buysse, K. and Verbeke, A. (2003). Proactive environmental strategies: a stakeholder management perspective. Strategic Management Journal 24(5), 453-470.

Cai, Y., Jo, H., and Pan, C. (2011). Vice or virtue? The impact of corporate social responsibility on executive compensation. Journal of Business Ethics, 104(2), 159-173.

Callan, S. J. and Thomas, J.M. (2011). Executive compensation, corporate social responsibility, and corporate financial performance: a multi-equation framework. Corporate Social Responsibility and Environmental Management, 18(6), 332-351.

Cheng, E. and Courtenay, S. M. (2006). Board composition, regulatory regime and voluntary disclosure. The International Journal of Accounting, 41(3), 262-289.

Clarkson, M. E. (1995). A stakeholder framework for analyzing and evaluating corporate social performance. Academy of Management Review, 20(1), 92-117.

Coombs, J.E. and Gilley, M.K. (2005). Stakeholder management as a predictor of CEO compensation: Main effects and interactions with financial performance. Strategic Management Journal, 26(9), 827-840.

Cordeiro, J. J. and Sarkis, J. (2008). Does explicit contracting effectively link CEO compensation to environmental performance? Business Strategy and the Environment, 17(5), 304-317. 
Cuevas-Rodríguez G., Gomez-Mejia L.R. and Wiseman R.M. (2012). Has Agency Theory Run its Course?: Making the Theory more Flexible to Inform the Management of Reward Systems. Corporate Governance: An International Review, 20(6), 526-546

Davis, J, Schoorman, F. and Donaldson, L. (1997). Toward a stewardship theory of management: The Academy of Management Review, 22(1), 20-47.

Deci, E. L. (1971). Effects of externally mediated rewards on intrinsic motivation. Journal of personality and Social Psychology, 18(1), 105-115.

Deckop, J. R., Merriman, K. K. and Gupta, S. (2006). The effects of CEO pay structure on corporate social performance. Journal of Management, 32(3), 329-342.

Deutsch, Y., and Valente, M. (2013). Compensating Outside Directors with Stock: The Impact on Non-Primary Stakeholders. Journal of Business Ethics, 116(1), 67-85.

DiMaggio, P., Powell, W. (1983). The iron cage revisited: institutional isomorphism and collective rationality in organizational fields. American Sociological Review, 48(2), 147-160.

Donaldson, L., and Davis, J. H. (1991). Agency theory or stewardship theory: CEO governance and shareholder returns. Australian Journal of Management, 16(1), 49-64.

Dowling, J. and Pfeffer, J. (1975). Organizational Legitimacy: Social Values and Organizational Behavior. The Pacific Sociological Review, 18(1), 122-136.

Driscoll, C. and Starik, M. (2004). The primordial stakeholder: Advancing the conceptual consideration of stakeholder status for the natural environment. Journal of Business Ethics, 49(1): 55-73.

Eesley, C. and Lenox, M.J. (2006). Firm responses to secondary stakeholder action. Strategic Management Journal, 27(8), 765-781. 
Eisenhardt, K. (1988). Agency- and Institutional-Theory Explanations: The Case of Retail Sales Compensation, The Academy of Management Journal, 31(3), 488-511.

Endrikat, J., Guenther, E., and Hoppe, H. (2014). Making sense of conflicting empirical findings: A meta-analytic review of the relationship between corporate environmental and financial performance. European Management Journal, forthcoming.

Esty, D. and Porter, M. (2005). National environmental performance: an empirical analysis of policy results and determinants. Environment and Development Economics, 10(4), 391-434.

Etzioni, A. (1986). The case for a multiple-utility conception. Economics and Philosophy, 2(02), 159-184.

Fehr, E. and Falk, A. (2002). Psychological Foundations of Incentives, European Economic Review, 46(4-5), 687-724.

Fernandes, N., Ferreira, M., Matos, P., and Murphy, K. (2013). Are U.S. CEOs Paid More? New International Evidence. Review of Financial Studies, 26(2), 323-367.

Filatotchev, I., and Allcock, D. (2010). Corporate governance and executive remuneration: A contingency framework. Academy of Management Perspectives, 24(1), 20-33.

Fiorino, D. J. (2006). The new environmental regulation. Mit Press.

Frank, R.H. (2003). What Price the Moral High Ground? Ethical Dilemmas in Competitive Environments. Princeton University Press. New Jersey.

Freeman, R. (1984). Strategic management: A stakeholder approach. Pitman Publishing Inc., Oxford.

Frey, B. S., and Jegen, R. (2001). Motivation crowding theory. Journal of economic surveys, 15(5), 589-611. 
Frye, M.B., E. Nelling, and E. Webb (2006) Executive Compensation in Socially Responsible Firms, Corporate Governance, 14(5), 446-455.

Godos-Díez, J. L., Fernández-Gago, R., \& Martínez-Campillo, A. (2011). How important are CEOs to CSR practices? An analysis of the mediating effect of the perceived role of ethics and social responsibility. Journal of Business Ethics, 98(4), 531-548.

Grolleau, G., Mzoughi, N. and Pekovic, S. (2012). Green not (only) for profit: An empirical examination of the effect of environmental-related standards on employees' recruitment. Resource and Energy Economics, 34(1), 74-92.

Hall, B.J. and Liebman, J.B. (1998). Are CEOs really paid like bureaucrats?. The Quarterly Journal of Economics, 113(3), 653-691.

Hernandez, M. (2008). Promoting stewardship behavior in organizations: A leadership model. Journal of Business Ethics, 80(1), 121-128.

Hill, C. and Jones, T. (1992). Stakeholder-agency theory. Journal of Management Studies, 29(2): 131-154.

Holländer, H. (1990). A social exchange approach to voluntary cooperation. The American Economic Review, 80(5), 1157-1167.

Ims, K. J., Pedersen, L. J. T., and Zsolnai, L. (2014). How Economic Incentives May Destroy Social, Ecological and Existential Values: The Case of Executive Compensation. Journal of Business Ethics, 123(2), 1-8.

Jackson G. and Apostolakou, A. (2010). Corporate Social Responsibility in Western Europe: An Institutional Mirror or Substitute? Journal of Business Ethics, 94(3), 371-394.

Jensen, M. and Meckling, W. (1976). Theory of the firm: Managerial behavior, agency costs and ownership structure. Journal of Financial Economics, 3(4), 305-360. 
Jensen, M. and Murphy, K. J. (1990). Performance pay and top management incentives. Journal of Political Economy, 98(2), 225-264.

Jensen, M. C., Murphy, K. J., \& Wruck, E. G. (2004). Remuneration: Where we've been, how we got to here, what are the problems, and how to fix them, Harvard Business School, Research Paper $04-28$

Jobome, G. O. (2006). Management pay, governance and performance: The case of large UK nonprofits. Financial Accountability \& Management, 22(4), 331-358.

Johnson, R. A. and Greening, D. W. (1999). The effects of corporate governance and institutional ownership types on corporate social performance. Academy of Management Journal, 42(5), 564576.

Jones, M.J. (2014). Accounting for Biodiversity, Routledge.

Jones, M.T. (1999). The Institutional Determinants of Social Responsibility The Institutional Determinants of Social Responsibility. Journal of Business Ethics 20(2), 163-179.

Jones, T. and Wicks, A. (1999). Convergent stakeholder theory. Academy of Management Review, 24(2), 208-221.

Kock, C. J., Santaló, J., and Diestre, L. (2012). Corporate governance and the environment: what type of governance creates greener companies?. Journal of Management Studies, 49(3), 492-514.

Kopel, M. and Brand, B. (2013). Why Do Socially Concerned Firms Provide Low-powered Incentives to Their Managers?, Working Paper.

Lyon, T. and Maxwell, W. (1999). "Voluntary" approaches to environmental regulation: A survey. Social Science Research Network Electronic Library.

Matten, D. and Moon, J. (2008). "Implicit" and "explicit" CSR: A conceptual framework for A comparative understanding of Corporate social responsibility. Academy of Management Review, $33(2), 404-442$. 
McGuire, J., Dow, S. and Argheyd, K. (2003). CEO incentives and corporate social performance. Journal of Business Ethics, 45(4), 341-359.

McWilliams, A. and Siegel, D. (2001), Corporate social responsibility: A theory of the firm perspective, Academy of Management Review, 26(1), 117-127.

Meyer, J. and Rowan B., (1977). Institutional organizations: formal structure as myth and ceremony, American Journal of Sociology, 83(2), 340-63.

Miles, P. and Miles, G. (2013). Corporate social responsibility and executive compensation: Exploring the link. Social Responsibility Journal, 9(1), 76-90.

Miller, J. S., Wiseman R.M. and Gomez-Mejia, L.R. (2002). The fit between CEO compensation design and firm risk. Academy of Management Journal, 45(4), 745-756.

Moriarty, J. (2009). How much compensation can CEOs permissibly accept?. Business Ethics Quarterly, 19(2), 235-250.

Murphy, K. J. (1999). Executive compensation. Handbook of labor economics, 3, 2485-2563.

Nyborg, K. and Zhang T. (2013). Is Corporate Social Responsibility Associated with Lower Wages? Environmental and Resource Economics, 55(1),107-117.

Riahi-Belkaoui, A. (1992). Executive compensation, organizational effectiveness, social performance and firm performance: An empirical investigation. Journal of Business Finance \& Accounting, 19(1), 25-38.

Rosen, S. (1982). Authority, control, and the distribution of earnings. The Bell Journal of Economics, 13(2), 311-323.

Russo, M. V., \& Fouts, P. A. (1997). A resource-based perspective on corporate environmental performance and profitability. Academy of management Journal, 40(3), 534-559. 
Sarkis, J., Gonzalez-Torre, P. and Adenso-Diaz, B. (2010). Stakeholder pressure and the adoption of environmental practices: The mediating effect of training, Journal of Operations Management, 28(2), 163-176.

Sen, A. (1987). On ethics and economics. Basil Blackwell, NY.

Shleifer, A. and Vishny, R. (1997). A survey of corporate governance. The Journal of Finance, 52(2), 737-783.

Stanwick, P.A. and Stanwick, S.D. (2001). CEO compensation: Does it pay to be green? Business Strategy and the Environment, 10(3), 176-182.

Stanwick, P.A. and Stanwick, S.D. (2003). CEO and ethical reputation: visionary or mercenary? Journal of Management Decision, 41(10), 1050-1057.

Sundaramurthy, C., \& Lewis, M. (2003). Control and collaboration: Paradoxes of governance. Academy of Management Review, 28(3), 397-415.

Tirole, J. (2002). Rational irrationality: Some economics of self-management. European Economic Review, 46, 633-655.

Tosi, H. and Gomez-Mejia, L. (1994). CEO Compensation Monitoring and Firm Performance The Academy of Management Journal, 37(4), 1002-1016.

Tosi H. L., Werner S., Katz J. P. and Gomez-Mejia L. R. (2000). How much does performance matter? A meta-analysis of CEO pay studies. Journal of Management, 26(2), 301-339.

Waddock, S.A. and Graves, S.B (1997). Quality of Management and Quality of Stakeholder Relations Are They Synonymous?. Business \& society, 36(3), 250-279.

Wasserman, N. (2006). Stewards, agents, and the founder discount: Executive compensation in new ventures. Academy of Management Journal, 49(5), 960-976. 
Wiseman, R. M., Cuevas Rodríguez, G., and Gomez Mejia, L. R. (2012). Towards a social theory of agency. Journal of Management Studies, 49(1), 202-222.

Wood, D. J. and Jones, R. E. (1995). Stakeholder mismatching: A theoretical problem in empirical research on corporate social performance. International Journal of Organizational Analysis, 3(3): 229-267. 
Table 1 - Environmental regulatory regime index (ERRI) by country

\begin{tabular}{rlr}
\hline & Country & \multicolumn{1}{c}{ Score } \\
\hline 1 Finland & 2.303 \\
2 & Sweden & 1.772 \\
3 & Singapore & 1.171 \\
4 & Netherlands & 1.747 \\
5 & Austria & 1.641 \\
6 & Switzerland & 1.631 \\
7 & Germany & 1.522 \\
8 & France & 1.464 \\
9 & Denmark & 1.384 \\
10 & United Kingdom & 1.185 \\
11 & United States & 1.184 \\
12 & Belgium & 1.159 \\
13 & Norway & 1.045 \\
14 & Ireland & 0.546 \\
15 & Italy & 0.498 \\
16 & Spain & 0.437 \\
17 & Portugal & -0.028 \\
\hline
\end{tabular}

Source: Esty and Porter (2005). 
Table 2 - Descriptive statistics. CEO compensation per country

\begin{tabular}{|c|c|c|c|c|c|c|c|c|c|c|c|}
\hline & \multirow[b]{2}{*}{ Obs. } & \multicolumn{5}{|c|}{ Total compensation $(\$ 000)$} & \multicolumn{5}{|c|}{ Incentive-based compensation ratio } \\
\hline & & Mean & Median & Std. dev. & Min & Max & Mean & Median & Std. dev. & Min & Max \\
\hline Austria & 2 & $2,077.0$ & $2,077.0$ & $1,324.0$ & $1,140.0$ & $3,013.0$ & 0.00 & 0.00 & 0.00 & 0.00 & 0.00 \\
\hline Belgium & 8 & $1,915.0$ & $1,293.0$ & $1,460.0$ & 605.0 & $4,205.0$ & 22 & 0.00 & 0.34 & 0.00 & 0.92 \\
\hline & 3 & $3,038.7$ & $2,000.0$ & $2,082.3$ & $1,680.0$ & $5,436.0$ & 0.2 & 0.00 & 0.48 & 0.00 & 0.83 \\
\hline Finland & 6 & $3,229.0$ & $1,273.0$ & & & $12,779.0$ & & 0.00 & 0.28 & 0.00 & 0.69 \\
\hline & 27 & $5,104.0$ & & & & & & & 0.21 & 0.00 & 0.85 \\
\hline & 32 & & & & & & & & & 0.00 & 0.62 \\
\hline & 5 & & & & 1,65 & & & & & 00 & 0.70 \\
\hline & 7 & $4,555.0$ & & & 820 & & & 0. & .00 & 0.00 & 0.00 \\
\hline & 26 & 2,930 & & & & & & & .27 & 0.00 & 0.79 \\
\hline Nor & 4 & $1,330.0$ & $1,316.0$ & 0.0 & $1,021.0$ & & & & 0.22 & 0.00 & 0.45 \\
\hline & 3 & $1,249.0$ & & 895.0 & 513.0 & & & & 0.10 & 0.00 & 0.17 \\
\hline & 1 & $31,054.0$ & $31,054.0$ & & $31,054.0$ & $31,054.0$ & & & & 0.93 & 0.93 \\
\hline & 4 & & & & & & & & .00 & 0.00 & 0.00 \\
\hline & 16 & & & & & & & 0. & 0.07 & 0.00 & 0.25 \\
\hline & 24 & 477.8 & & $6,51 ?$ & & 27,2 & & & 0.38 & 0.00 & 1.00 \\
\hline & 75 & $6,004.8$ & $4,682.0$ & $4,477.6$ & 859.0 & $19,720.0$ & & & 0.23 & 0.00 & 0.89 \\
\hline United Stat & 277 & $15,293.4$ & $11,530.0$ & $15,208.6$ & 46.0 & $135,642.0$ & 0.83 & 0.89 & 0.20 & 0.00 & 1.00 \\
\hline Total sample & 520 & $10,242.5$ & $6,759.0$ & $12,716.6$ & 46.0 & $135,642.0$ & 0.27 & 0.16 & 0.26 & 0.00 & 1.00 \\
\hline
\end{tabular}


Table 3 - Descriptive statistics. Environmental performance and control variables

\begin{tabular}{lrrrrr}
\hline Variable & Mean & Median & Std. Dev. & Min & Max \\
\hline Environmental Performance (EP) & 45.04 & 44.27 & 13.82 & 18.18 & 81.03 \\
ERRI scores & 1.27 & 1.18 & 0.28 & -0.03 & 2.30 \\
Firm size $\left({ }^{\mathrm{a}}\right)$ & 21,500 & 7,725 & 38,400 & 142.86 & 372,000 \\
Stock return $(\%)$ & -37.07 & -37.95 & 24.73 & -94.36 & 77.18 \\
ROA $(\%)$ & 5.64 & 5.90 & 10.69 & -85.26 & 34.84 \\
Debt ratio & 0.63 & 0.64 & 0.19 & 0.11 & 1.54 \\
Firm risk & 0.95 & 0.93 & 0.34 & 0.08 & 2.64 \\
Agriculture, mining and & 0.10 & & & & \\
construction & 0.20 & & & & \\
Light manufacturing & 0.29 & & & & \\
Heavy manufacturing & 0.15 & & & & \\
Transports, communication and & 0.12 & & & & \\
utilities & 0.14 & & & & \\
Trade & & & & \\
Other industries $\left({ }^{b}\right)$ & & & & & \\
\hline
\end{tabular}

$\left({ }^{a}\right)$ Firm size is measured in total assets expressed in millions of euros.

$\left({ }^{b}\right)$ Because of the reduced number of firm observations in the real-estate, services and public administration industries, we grouped together such firm observations in the residual category "other industries". 
Table 4 - Correlation matrix

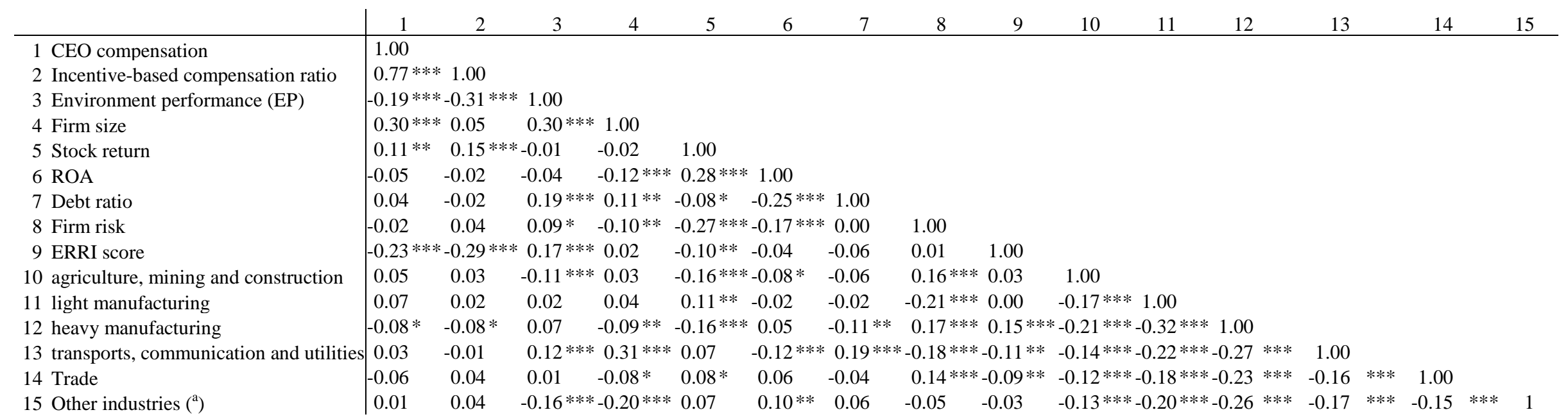

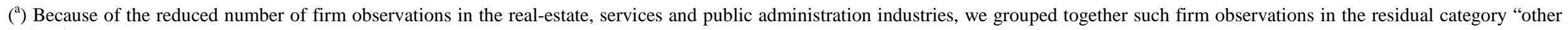
industries".

$* p<0.10, * * p<0.05, * * * p<0.01$ 
Table 5 - Multivariate analysis.

\begin{tabular}{|c|c|c|c|c|}
\hline & $\begin{array}{c}\text { (1) } \\
\text { Incentive-based } \\
\text { compensation ratio }\end{array}$ & $\begin{array}{c}(2) \\
\text { Total } \\
\text { compensation }\end{array}$ & $\begin{array}{c}(3) \\
\text { Incentive-based } \\
\text { compensation ratio }\end{array}$ & $\begin{array}{c}(4) \\
\text { Total } \\
\text { compensation }\end{array}$ \\
\hline \multicolumn{5}{|l|}{ Environmental } \\
\hline Performance (EP) & $\begin{array}{c}-0.009 \\
(0.000) * * *\end{array}$ & $\begin{array}{c}-0.010 \\
(0.000)^{* * *}\end{array}$ & $\begin{array}{c}-0.009 \\
(0.000)^{* * *}\end{array}$ & $\begin{array}{c}-0.010 \\
(0.000)^{* * *}\end{array}$ \\
\hline ERRI score & $\begin{array}{c}-0.304 \\
(0.000)^{* * *}\end{array}$ & $\begin{array}{c}-0.341 \\
(0.000)^{* * *}\end{array}$ & $\begin{array}{c}-0.372 \\
(0.000)^{* * *}\end{array}$ & $\begin{array}{c}-0.436 \\
(0.000)^{* * *}\end{array}$ \\
\hline $\mathrm{EP} \times \mathrm{ERRI}$ score & & & $\begin{array}{c}0.010 \\
(0.011)^{* *}\end{array}$ & $\begin{array}{c}0.013 \\
(0.007)^{* * *}\end{array}$ \\
\hline Firm Size & $\begin{array}{c}0.044 \\
(0.000)^{* * *}\end{array}$ & $\begin{array}{c}0.147 \\
(0.000)^{* * *}\end{array}$ & $\begin{array}{c}0.039 \\
(0.001)^{* * *}\end{array}$ & $\begin{array}{c}0.138 \\
(0.000)^{* * *}\end{array}$ \\
\hline Stock return & $\begin{array}{c}0.003 \\
(0.000)^{* * *}\end{array}$ & $\begin{array}{c}0.003 \\
(0.001)^{* * *}\end{array}$ & $\begin{array}{c}0.003 \\
(0.000)^{* * *}\end{array}$ & $\begin{array}{c}0.003 \\
(0.000)^{* * *}\end{array}$ \\
\hline $\mathrm{ROA}$ & $\begin{array}{l}-0.002 \\
(0.208)\end{array}$ & $\begin{array}{l}-0.002 \\
(0.366)\end{array}$ & $\begin{array}{l}-0.002 \\
(0.159)\end{array}$ & $\begin{array}{l}-0.002 \\
(0.288)\end{array}$ \\
\hline Debt ratio & $\begin{array}{c}0.022 \\
(0.787)\end{array}$ & $\begin{array}{c}0.146 \\
(0.177)\end{array}$ & $\begin{array}{c}0.023 \\
(0.773)\end{array}$ & $\begin{array}{c}0.148 \\
(0.169)\end{array}$ \\
\hline Firm risk & $\begin{array}{c}0.130 \\
(0.006)^{* * * *}\end{array}$ & $\begin{array}{c}0.106 \\
(0.093)^{*}\end{array}$ & $\begin{array}{c}0.126 \\
(0.008)^{* * *}\end{array}$ & $\begin{array}{c}0.100 \\
(0.110)\end{array}$ \\
\hline Constant & $\begin{array}{c}0.233 \\
(0.286)\end{array}$ & $\begin{array}{c}1.786 \\
(0.000)^{* * *}\end{array}$ & $\begin{array}{l}-0.058 \\
(0.778)\end{array}$ & $\begin{array}{c}1.487 \\
(0.000)^{* * *}\end{array}$ \\
\hline $\begin{array}{l}\text { Industry Fixed } \\
\text { effects }\end{array}$ & Included & Included & Included & Included \\
\hline $\mathrm{F}$ & $\begin{array}{c}18.570 \\
(0.000)^{* * *}\end{array}$ & $\begin{array}{c}21.550 \\
(0.000)^{* * *}\end{array}$ & $\begin{array}{c}17.250 \\
(0.000)^{* * *}\end{array}$ & $\begin{array}{c}20.020 \\
(0.000)^{* * *}\end{array}$ \\
\hline Adjusted $\mathrm{R}^{2}$ & 0.192 & 0.223 & 0.201 & 0.233 \\
\hline Obs. & 520 & 520 & 520 & 520 \\
\hline Mean VIF & 1.76 & 1.76 & 1.75 & 1.75 \\
\hline Max VIF & 2.97 & 2.97 & 2.98 & 2.98 \\
\hline
\end{tabular}

$p$-values in parentheses

${ }^{*} p<0.10,{ }^{* *} p<0.05, * * * p<0.01$ 